methodically to persevere in the conjoint use of all means likely to promote recovery until we are convinced that further effort is futile.

Upper Berkeley-street, $w$.

\section{ENDOCARDITIS OF TRICUSPID AND MITRAL VALVES OCCURRING IN A COLLIE BITCH THE SUBJECT OF CHOREA.}

BY R. D. MOTHERSOLE, M.S., M.D. LOND., HONORARY SURGEON TO THE BOLTON INFIRMARY.

WHILE visiting a patient last May my attention was called to a collie bitch fourteen months old, said to be suffering from St. Vitus's dance. The bitch had enjoyed good health up till the age of seven months, when she had an attack of distemper, with the following symptoms. It was said to have begun "like a cold; eyes first red and then covered with a film, running from the nose, heaving and bilious vomiting, and feverishness." From this attack she gradually recovered after one or two relapses. About this time the animal received a severe blow on the head from a heary stone. The spasmodic movements began in November, and had since got worse, while she also lost flesh and became weaker. I was likewise informed that a sister bitch had an attack of distemper at about the same time, which was likewise followed by convalsive movements. These partly took the form of constant hiccough, and on this account she was destroyed. When I first saw this case the bitch was suffering from clonic spasms, principally affecting the right limbs. but also the muscles of the trunk and abdomen, and, to a less extent, the left side. The movements were at the rate of sixty to sixty-five per minute, and when she was lying down the whole body moved. The muscular spasm frequently made the inspirations of a convulsive or "catchy" nature. The movements appeared to cease for a few seconds when she made a determined effort, or under the influence of excitement, but soon returned. The owner stated that the movements did not cease during sleep; probably they prevented sleep, as the poor animal was heard "bumping against her kennel" in the night time. The body was somewhat emaciated, and the skin of her nose was hot and dry. The hot weather appeared to have an unfavourable influence on her health, and she became weaker and more irritable. The bitch was, therefore, destroyed with prussic acid eight days after I first saw ber. Thirteen hours later I made a partial post-mortem examination. The body was not very well nourished, there being only a small amount of subcutaneous fat. There were some small ecchymoses on the surface of the thymus and beneath the pleura and pericardium, probably attributable to the mode of death. The heart was rather larger than might have been expected. The pulmonary valves were normal. The septal segment of the tricuspid valve presented a very unusual appearance; it was of a cherry-red colour and much thickened, being made up of what appeared to be granulation tissue one-sixteenth of an inch thick; it was also much narrowed, so that the distance from the origin to the free edge was only about half of that in the other segments. The chordæ tendineæ were much shorter than usual, and were inserted bebind the thickened free edge of the valve. The endocardium at the origin of this part of the valve was mottled, and showed one or more small vessels running in the direction of the inflamed segment. The other segments of the tricuspid valve were almost normal, but showed a few small granulations near the insertion of the chordx. The aortic valves appeared normal with the exception of a small, bard, calcareous nodule projecting from the upper border of one sinus of Valsalva. Both segments of the mitral valve showed numerous small, bright-red, semi-translucent granulations, springing from the auricular aspect of the valve near the origin of the chordæ tendineæ. They varied in size from a mustard- to a millet.seed, could not be rubbed off, and evidently formed part of the substance of the valve.

This case is of considerable interest as indicating a relationship between chorea and endocarditis in the lower animals as well as in the human subject. I have since been informed that chorea is not infrequently met with in the dog, and bave also heard of another case in which it followed an attack of distemper. Such an association, if common, is wortby of attention in regard to the connexion of chorea with acute rbeumatism and other febrile diseases in children. Unfortunately, this case does not throw any direct ljght on the vexed question of the pathology of chorea. It appears to best coincide with the view that chorea is the result of impairment of inhibitory power in an unstable nervous organisation, either by a toxic agent in the blood or some other disturbing cause. In this case the spasmodic movements were antecedent to the endocarditis, and the idea suggests itself whether they may not have caused the latter by throwing increased strain on the cardiac valves, whose nutrition had been already impaired by the condition of the blood. The fact that one segment of the tricuspid was more diseased than any part of the mitral valve may possibly be explained on the supposition that this segment had been already the seat of congenital disease. This hypothesis would be supported by the condition of the chordæ tendineæ.

Bolton.

\section{Climital allotes:}

MEDICAL, SURGICAL, OBSTETRICAL, AND THERAPEUTICAL.

\section{CASE OF DISLOCATION OF BOTH BONES OF THE} ELBOW-JOIN'T OUTWARDS.

By C. Frank Wightman, M.R.C.S. Eng., L.R.C.P. Lond., SEYIOR HOUSE SURGEON TO THE SCARBOROUGH HOSPITAT ATD DISPEXSARY.

THE following case of dislocation of the elbow-joint outwards seems to me to be worthy of record on account of its rareness. The patient, a boy nine years old, who was brought to the hospital on Aug. 22nd, had, while playing on the sands, been knocked over. The patient could not tell me exactly how he fell, only that he fell on to his right elbow. On examination the forearm was found to be very slightly flexed and only very slightly pronated. The relative positions of the different bones of the elbow-joint were easily made out, as at the time of examination little or no swelling had occurred, the ulna being situated immediately below the external condyle of the humerus and the radius being external to this, in its normal relation to the ulna there being no radio-ulnar dislocation. The internal condyle was very prominent, the smooth, trochlear surface of the humerus being easily felt. There was no fracture of the coronoid process of the ulna. The dislocation was easily reduced, the ulva being freed from the external condyle by pressure with the knee while extension was made on the forearm. No anæsthetic was used. Dislocations of both bones of the elbow-joint outwards are certainly rare, and when met with, unlike this case, are nearly always accompanied by extreme pronation of the forearm.

Scarborough.

\section{UNUSUAL CASE OF SCARLET FEVER.}

By Philip J. Kavanage, L.R.C.P., L.R.C.S. Eidis., L.F.P. \& S. GLASG.

A FEW weeks ago I was called to visit a female child aged seven years and nine months, who was supposed to be suffering from measles. The mother informed me that on the previous day the child had complained of feeling unwell and had vomited twice, and that, whilst putting her to bed, she had observed the rash, which she thought was measles. On examination I was at once able to exclude measles. The body was covered with innumerable minute pink spots. which disappeared on pressure and did not feel elevarted to the touch. The spots on the chest, abdomen, and back were closely set, but did not unite with one another. The upper and lower extremities prezented the rash in 